\title{
BIOINFORMATICS ONLINE SUPPORT FOR BIOACTIVE SUBSTANCES CYTOTOXICITY TESTING AND THEIR STATISTICAL ANALYSIS
}

\author{
Stefan Z. Blagojević ${ }^{*}$, Vladimir M. Cvjetković ${ }^{2}$ Aleksandra G. Nikezić1, \\ Milena G. Milutinović1 ${ }^{\text {, Snežana D. Marković }}{ }^{1}$ \\ ${ }^{1}$ University of Kragujevac, Faculty of Science, Department of Biology and Ecology, \\ ${ }^{2}$ University of Kragujevac, Faculty of Science, Department of Physics, \\ Radoja Domanovića 12, 34000 Kragujevac, Serbia \\ *Corresponding author; E-mail: stefan.blagojevic@ pmf.kg.ac.rs
}

(Received May 4, 2020; Accepted May 10, 2020)

\begin{abstract}
Preclinical in vitrolin vivo testing is the first step in discovery of anticancer medicines, among others evaluation of cytotoxic activity of bioactive substances (BAS) on various human normal and cancer cell lines. Cytotoxicity expressed as $\mathrm{IC}_{50}$ value (a dose that inhibits $50 \%$ of cell growth) is one of the most commonly used parameter for comparable analysis of activity between different substances. This study includes examination of number of BAS and their results for cytotoxic activity obtained in the Laboratory for cell and molecular biology (LCMB) that require various statistical and computational techniques for proper effective analysis. In order to improve experimental data analysis, make it faster, more effective, error proof with secure online data repository, a web application with $\mathrm{LCMB} \mathrm{IC}_{50}$ database was developed as a useful research tool acting as a leverage for scientific data processing requirements. Analysis includes cytotoxic effects of chemical and natural BAS ( IC $_{50}$ values) on HCT-116, SW-480, MDA-MB-231, and MRC-5 cell lines. Generally, it can be concluded that BAS of different origin, chemical or natural, have various cytotoxic effects and cause different cell line sensitivity, which is presented and discussed. This paper presents developed SQL database-centric web application with remote user-friendly data management for a biology researcher user type profile. Data processing in this article can be useful for a further overlook and testing of cytotoxic substances.
\end{abstract}

Keywords: ANOVA, cancer cell lines, $\mathrm{LCMB}_{\mathrm{IC}}{ }_{50}$ database, remote access.

\section{INTRODUCTION}

Cancer represents one of the most common diseases worldwide. There are many attempts to improve anticancer therapy, where one of the main is using a variety of drugs from different origins and mechanisms of action. All of them must pass through preclinical and clinical testing on diverse model systems (LOPEZ-LAZARO, 2015). The preclinical investigations begin with isolation, purification and/or modification of bioactive substances (BAS) 
originating from natural sources, as well as the synthesis of new chemical compounds. They include testing of structural characteristics, their interaction with biomacromolecules and many assays that evaluate their anticancer properties, mainly on the recommended panels of cell lines and animal models. In vitro cytotoxic testing of BAS on cancer cell lines allows early detection of cytotoxic treatments that potentially can be used in anticancer therapy (FLORENTO et al., 2012). Testing the effect of different BAS on cell viability in culture is a widely used method. There are a large number of in vitro cytotoxicity assays to test whether a compound is toxic to cultured cells or not, mainly by determining the number of living cells, over a defined incubation period (RISS et al., 2011). Inhibitory concentration (IC50) of a testing substance that inhibits $50 \%$ of cell growth is a referent value for cytotoxicity (CALDWELL et al., 2012; ĆURČIĆ et al., 2012a). Intensive research in this field, and the large number of results for cytotoxicity obtained from various active substances, and their use in the prevention and treatment of cancer (MiLUTINOvić et al., 2015a), lead to statistical processing of these data and implementation of new LCMB IC 50 database presented in this article.

The anticancer activity of chemical complexes has been known for decades and many of them have been used as a treatment for various types of cancer (NDAGI et al., 2017). The impressive effect of cisplatin on cancer cells has launched develop of new derivatives with improved pharmaceutical effects. In recent years, various chemical compounds and metalbased complexes have been increasingly tested, such as platinum, palladium, gold, ruthenium, etc. have been synthesized with different ligands (PETROVIĆ et al., 2015; NDAGI et al., 2017; ŽIVANOVIĆ et al., 2017; RADISAVLJEVIĆ et al., 2019; MEDJEDOVIĆ et al., 2020).

Natural products isolated from medicinal plants, whether as pure compounds or as extracts, provide limitless opportunities for obtaining new antitumor drugs (CHEN et al., 2012). More than $50 \%$ of cancer patients in the USA use agents originating from plants or nutrients, either solely or in combination with chemotherapy (WANG et al., 2012). Many of plant extracts were recommended as noticeable cytotoxic substances on various cancer cell lines (StAnKOVIĆ et al., 2011; ĆURČIĆ et al., 2012a; MilutinoviĆ et al., 2015b; MiLuTinoVIĆ et al., 2019b). The main advantage of BAS from natural origin is cell selectivity, where they affect cancer but not normal, healthy cells (MiluTinOVIĆ et al., 2015a; MiLUTINOVIĆ et al., 2019b). The reported anticancer properties of natural products, including the plant, mushroom and lichen extracts were mainly by induction of apoptosis, modulation of redox status in the cancer cell lines, antimigratory and antiinvasive effects (MiLUTINOVIĆ et al., 2015a; Šeklić et al., 2016; CVetKoviĆ et al., 2019; MilutinOviĆ et al., 2019b). In the Laboratory for cell and molecular biology (LCMB), the cytotoxicity of more than 50 chemically synthesized compounds was examined, as well as over 200 substances from natural origin. Thus, there was the need for collecting $\mathrm{IC}_{50}$ data of various BAS sources in the LCMB $\mathrm{IC}_{50}$ database for efficient analysis and comparison of cytotoxic effects between different cell lines, as well as within the treatment incubation period, 24 and $72 \mathrm{~h}$. Also, the difference in the cytotoxic effect of BAS isolated from plants, fungi or lichens depending on cell lines and incubation period, as well as for the type of extract used for isolation was further analyzed.

Besides required complex laboratory procedures and tests, which are subject to permanent innovation and improvement, adequate support for large amounts of laboratory data processing becomes increasingly important. Laboratories generate more and more data that need to be adequately processed in order to extract new scientific information and produce new research insights and discoveries. Usual manual data processing supported with various software tools that require significant human assistance like excel tables and similar, cannot cope with increasing data amount, slow and error-prone processing due to required intensive human interaction while having limited data processing and interpretation capabilities and lacking support for complex data processing, decomposition and restructuring. Decomposition and data restructuring (EMELYANOV, 2018) can relate and organize existing data in a new way offering previously unavailable insights and aspects, discovering "hidden" information 
which may lead to new scientific achievements, thus giving added value and use of collected laboratory data.

The aims of this study are: (1) collecting $\mathrm{IC}_{50}$ values in LCMB IC 50 database for easy and rapid analysis of given effects BAS cytotoxicity and comparison of cytotoxic effects of different sources of BAS, and (2) developing a web application for remote management of database, containing laboratory data, supporting different modes of operation such as: adaptive filtering for data selection and statistical analysis, parameter and data CRUD (Create Read Update Delete) operations for manipulation of parameter data characterizing IC $_{50}$ values and $\mathrm{IC}_{50}$ data edit. All web application operational modes are available remotely, using an intuitive web user interface for a logged-in user.

\section{MATERIALS AND METHODS}

\section{Description of Laboratory data and methods}

Collected Laboratory data for $\mathrm{IC}_{50}$ values are based on the results of the researches performed within the Laboratory for Cell and Molecular Biology, Faculty of Science, University of Kragujevac for the 2010-2020 period. In these researches, 115 different treatments for HCT-116, 56 for SW-480, 62 for MDA-MB-231, and 19 for the MRC-5 cell line were examined. All researches were carried out within the framework of a scientific research project of the Ministry of Education, Science and Technological Development of the Republic of Serbia (Preclinical testing of bioactive substances - PIBAS, III41010).

Human adherent colorectal carcinoma cell line (HCT-116), colorectal adenocarcinoma (SW-480), breast carcinoma cell line (MDA-MB-231), and the human fetal lung fibroblasts(MRC-5), as normal cell line, were obtained from ATCC (American Type Culture Collection, Manassas, VA, USA). Cells were cultured in the optimum conditions, according to standard protocols (MILUTINOVIĆ et al., 2019a). The cytotoxicity of various substances on cell lines was examined using the MTT cell viability assay (MOSMANN, 1983). For the purpose of this essay, cells were seeded in 96-well plate, incubated for $24 \mathrm{~h}$ and then treated with different substances in a concentration range of 0.1 to $500 \mu \mathrm{M}$ for chemically synthesized or 0.1 to 500 $\mu \mathrm{g} / \mathrm{ml}$ for natural extracts. The assay was performed 24 and $72 \mathrm{~h}$ after treatments.

Percentages of cell viability were calculated as the ratio of absorbance of the treated group divided by the absorbance of the control group (untreated cells), multiplied by 100 . The $\mathrm{IC}_{50}$ value was presented as the parameter for cytotoxicity and comparable result between different substances. The $\mathrm{IC}_{50}$ values were calculated from dose curves of cell viability using CalcuSyn v 2.1. software. The $\mathrm{IC}_{50}$ values of BAS are grouped according to their origins, such as chemically synthesized (CHS) and natural extracts (NE). The data of natural extracts are grouped according to treatment taxonomy type: plants, fungi, lichens, as well as according to the type of extract used in extraction procedures: methanol, acetone and other types (ethanol, ethyl acetate, water, chloroform and petroleum ether).

\section{Statistical analysis of $I_{50}$ data}

Statistical analysis of $\mathrm{IC}_{50}$ data was performed in the web application within the LCMB IC $_{50}$ database presented in this article. The results are presented as mean \pm standard error. Analysis of variance (ANOVA) on web application was used as a test to compare selected data. All data that were not read by MTT (values of 0 ) were excluded from the statistics by filtering and eliminating those values. All data greater than 500 (values $>500 \mu \mathrm{M}$, and $>500 \mu \mathrm{g} / \mathrm{ml}$ ) were considered as non-cytotoxic and their values were included in statistics as values of 500 . 


\section{LCMB IC 50 database description}

Starting point for a database and web application development was a collection of Laboratory data for $\mathrm{IC}_{50}$ organized in the form of a single excel table. In the table, columns were $\mathrm{IC}_{50}$ laboratory research data and various parameters characterizing experimental conditions of obtained $\mathrm{IC}_{50}$ data. Each of more than 360 table lines corresponds to the results of particular lab experiment. Such organization and storage of experimental data offered some basic features for results analysis, while more advanced specific custom analysis and teamwork requirements could not be met with a single table document, even with shared document collaborative environment in the cloud, such as Google disk, Microsoft One drive and other. Such collaborative cloud environments are suitable for teamwork where standard documents like excel, word, and similar are appropriate. Specific analysis features required data decomposition and relational database storage, together with development of an application with custom functionalities. Custom web application for remote management of database containing decomposed laboratory data within safe Faculty's academic network domain was considered as an optimal solution. Figure 1 presents part of the spreadsheet with original Laboratory data.

\begin{tabular}{|c|c|c|c|c|c|c|c|}
\hline 4 & A & B & C & D & $\mathrm{E}$ & $\mathrm{F}$ & G \\
\hline 1 & Treatment & IC50 unit & Type of treatment & Vell line & Type of extract & - 24h & $72 \mathrm{~h}$ \\
\hline 2 & 2-(phenylselenomethyl)tetrahydrofuran & $\mu \mathrm{M}$ & Chemical compound & HCT-116 & & $>500$ & $>500$ \\
\hline 3 & 2-(phenylselenomethyl)tetrahydropyran & $\mu \mathrm{M}$ & Chemical compound & HCT-116 & & $>500$ & $>500$ \\
\hline 45 & 5-Fluorouracil & $\mu \mathrm{M}$ & Chemical compound & HCT-116 & & $0.022 \pm 0.006$ & $1.35 \pm 0.38$ \\
\hline 5 & Allium flavum & $\mu \mathrm{g} / \mathrm{ml}$ & Plant & HCT-116 & Methanol & $28.29 \pm 1.24$ & $35.09 \pm 0.91$ \\
\hline 6 & Allium flavum & $\mu \mathrm{g} / \mathrm{ml}$ & Plant & HCT-116 & Ethylacetate & $84.76 \pm 1.21$ & $35.00 \pm 1.39$ \\
\hline 7 & Allium flavum & $\mu \mathrm{g} / \mathrm{ml}$ & Plant & HCT-116 & Aceton & $62.17 \pm 1.19$ & $14.80 \pm 1.39$ \\
\hline 8 & Allium flavum and $0.1 \mu \mathrm{M} \mathrm{Pd}(\mathrm{II})$ complex (palladium(II) complex with 3-[(2-hy & $\mathrm{y} \mu \mathrm{M}$ & Cotreatment & HCT-116 & Methanol & $12.85 \pm 0.13$ & $10.51 \pm 1.01$ \\
\hline 9 & Allium flavum and $0.1 \mu \mathrm{M} \mathrm{Pd}(\mathrm{II})$ complex (palladium(II) complex with $3-[(2$-hy & $\mathrm{y \mu \textrm {M }}$ & Cotreatment & HCT-116 & Ethylacetate & $186.14 \pm 3.29$ & $32.21 \pm 2.32$ \\
\hline 10 & Allium flavum and $0.1 \mu \mathrm{M} \mathrm{Pd}(\mathrm{II})$ complex (palladium(II) complex with 3-[(2-hyp & $y \mu \mathrm{M}$ & Cotreatment & HCT-116 & Aceton & $7.92 \pm 0.35$ & $16.84 \pm 0.89$ \\
\hline 11 & Allium flavum and $10 \mu \mathrm{M} \mathrm{Pd}(\mathrm{II})$ complex (palladium(II) complex with 3-[(2-hyc & $\mathrm{c} \mu \mathrm{M}$ & Cotreatment & HCT-116 & Methanol & $1.60 \pm 0.05$ & $1.74 \pm 0.08$ \\
\hline 12 & Allium flavum and $10 \mu \mathrm{M} \mathrm{Pd}(\mathrm{II})$ complex (palladium(II) complex with 3 -[(2-hych & $\mathrm{c} \mu \mathrm{M}$ & Cotreatment & HCT-116 & Ethylacetate & $0.016 \pm 0.001$ & $1.13 \pm 0.02$ \\
\hline 13 & Allium flavum and $10 \mu \mathrm{M} \mathrm{Pd}(I I)$ complex (palladium(II) complex with 3-[(2-hyc & $\mathrm{d} \mu \mathrm{M}$ & Cotreatment & HCT-116 & Aceton & $2.49 \pm 0.12$ & $3.74 \pm 0.02$ \\
\hline 14 & Au complex - SR06 (dinuclear gold(III) complexes with bidentate ligand 1,4-di; & $\mathrm{i}, \mu \mathrm{M}$ & Chemical compound & HCT-116 & & 72,62 & 29,88 \\
\hline 15 & Au complex - SR13 (dinuclear gold(III) complexes with bidentate ligand 1,8-di; & $\mathrm{i} \mu \mathrm{M}$ & Chemical compound & HCT-116 & & 60,17 & 37,16 \\
\hline 16 & Au complex - SR32 (trinuclear gold(III) complexes with bidentate ligand 1,8-dif & $\mathrm{i} \mu \mathrm{M}$ & Chemical compound & HCT-116 & & 63,34 & 133,87 \\
\hline 17 & Au complex - SR33 (trinuclear gold(III) complexes with bidentate ligand 1,6-dif & $\mathrm{i} \mu \mathrm{M}$ & Chemical compound & HCT-116 & & 23,28 & 24,18 \\
\hline 18 & Au complex - SR34 (trinuclear gold(III) complexes with bidentate ligand 1,4-di & $\mathrm{i} \mu \mathrm{M}$ & Chemical compound & HCT-116 & & 0,25 & 15,88 \\
\hline 19 & Au complex-SR14 (dinuclear gold(III) complexes with bidentate ligand 1,6-dia & $\mu \mathrm{M}$ & Chemical compound & HCT-116 & & 56,5 & 52,03 \\
\hline 20 & Cladonia foliacea & $\mu \mathrm{g} / \mathrm{ml}$ & Lichen & HCT-116 & Methanol & $265.554 \pm 13.27$ & $7122.474 \pm 9.79$ \\
\hline 21 & Coprinus comatus & $\mu \mathrm{g} / \mathrm{ml}$ & Fungus & HCT-116 & Methanol & $>500$ & $>500$ \\
\hline 22 & Cordyceps sinensis & $\mu \mathrm{g} / \mathrm{ml}$ & Fungus & HCT-116 & Methanol & $>500$ & $>500$ \\
\hline 23 & Cisplatin (cis-diamindihloroplatina(II)) & $\mu \mathrm{M}$ & Chemical compound & HCT-116 & & $263.66 \pm 8.02$ & $104.41 \pm 9.01$ \\
\hline
\end{tabular}

Figure 1. Original spreadsheet Laboratory data.

Excel data were converted to an equivalent database table. For a web application with required functionalities, data from the obtained table should be decomposed on a number of tables containing data of the same kind corresponding to data in spreadsheet columns. Decomposition is performed programmatically by SQL queries executed from phpMyadmin (https://www.phpmyadmin.net/) database tool or PHP program files (https://www.php.net/). PHP is used as a web server programming language for web applications. Table expdatadecomp is used as the main table joining decomposed data from other tables that are connected with lines in Figure 2 which shows the LCMB IC 50 database. Other important tables are for instance table sample containing dynamic definition of samples for ANOVA statistic test. Dynamic definition means that only values of parameters defining sample are stored, not sample data, which are dynamically obtained by SQL query when needed, according to the principle of storing only fundamental data and calculating dependent data. 


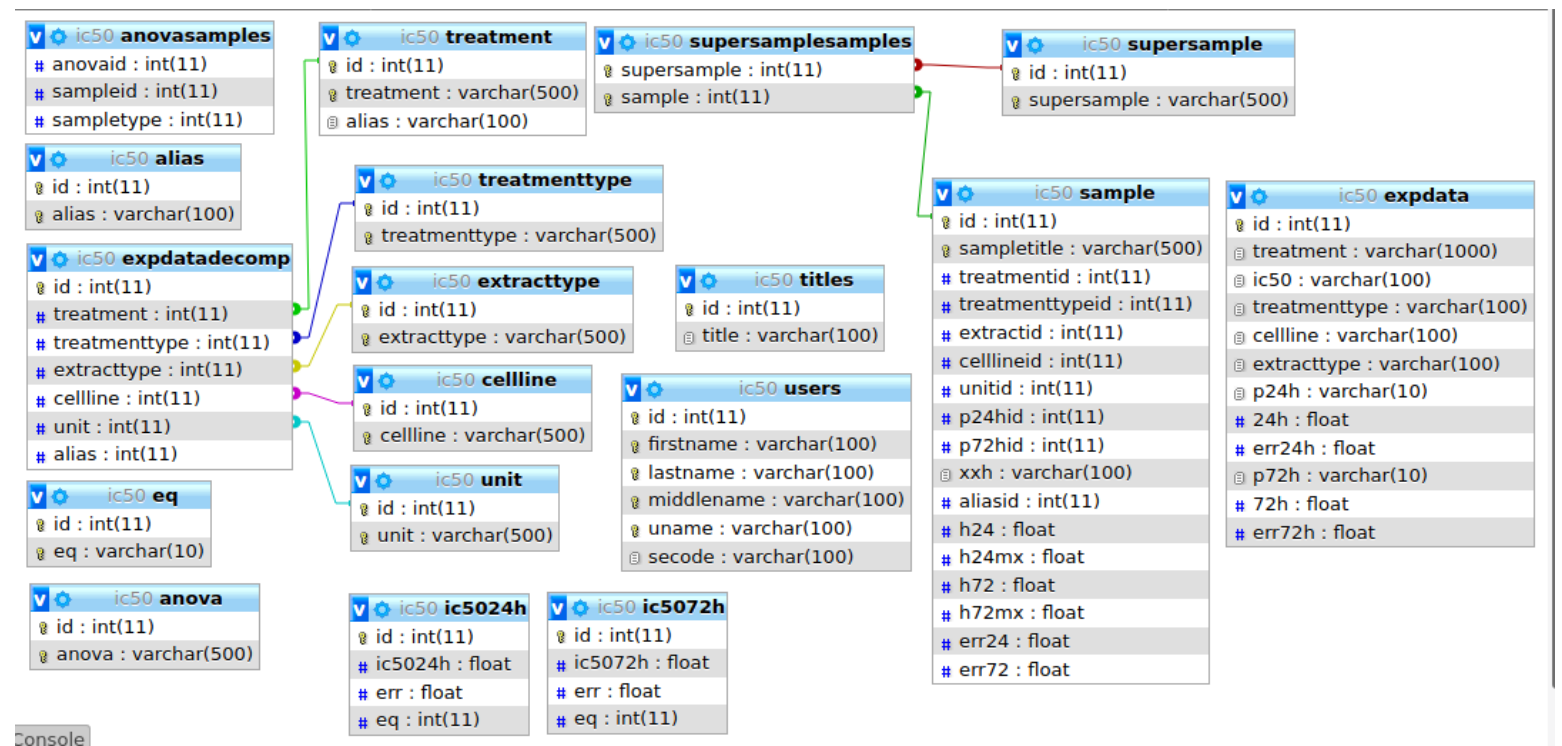

Figure 2. Relational view of $\mathrm{LCMB} \mathrm{IC}_{50}$ database.

\section{Web application}

Web application page for remote access and management of $\mathrm{IC}_{50}$ data is presented in Figure 3. There are 3 main functionalities of $\mathrm{IC}_{50}$ web application: 1) data view with flexible filtering, 2) data management CRUD operations, and 3) ANOVA statistical analysis including flexible samples creation, single and compound samples. Each of these functionalities includes many other sub functionalities. Any number of filtering conditions can be selected, and only selected parameters actually contribute to filtering. Figure 4 shows the case of data filtering that returns only 2 data rows. Without selection of any filtering parameter, all data are returned, as in Figure 3 where all 360 existing rows are returned. Filtering parameters are: Treatment specifying exact name of the treatment, Alias specifies the name of the treatment more closely, Type specifying type of the treatment, Line for cell line which is used for testing, Unit for $\mathrm{IC}_{50}$ and additional filtering parameters. Additional filtering parameters allow specifying 24 or 72 hours interval for applying cytotoxic substance, filtering according to $\mathrm{IC}_{50}$ value interval, lower and upper interval value for 24 and $72 \mathrm{~h}$ separately, and finally filtering according to $\mathrm{IC}_{50}$ error concentration value.

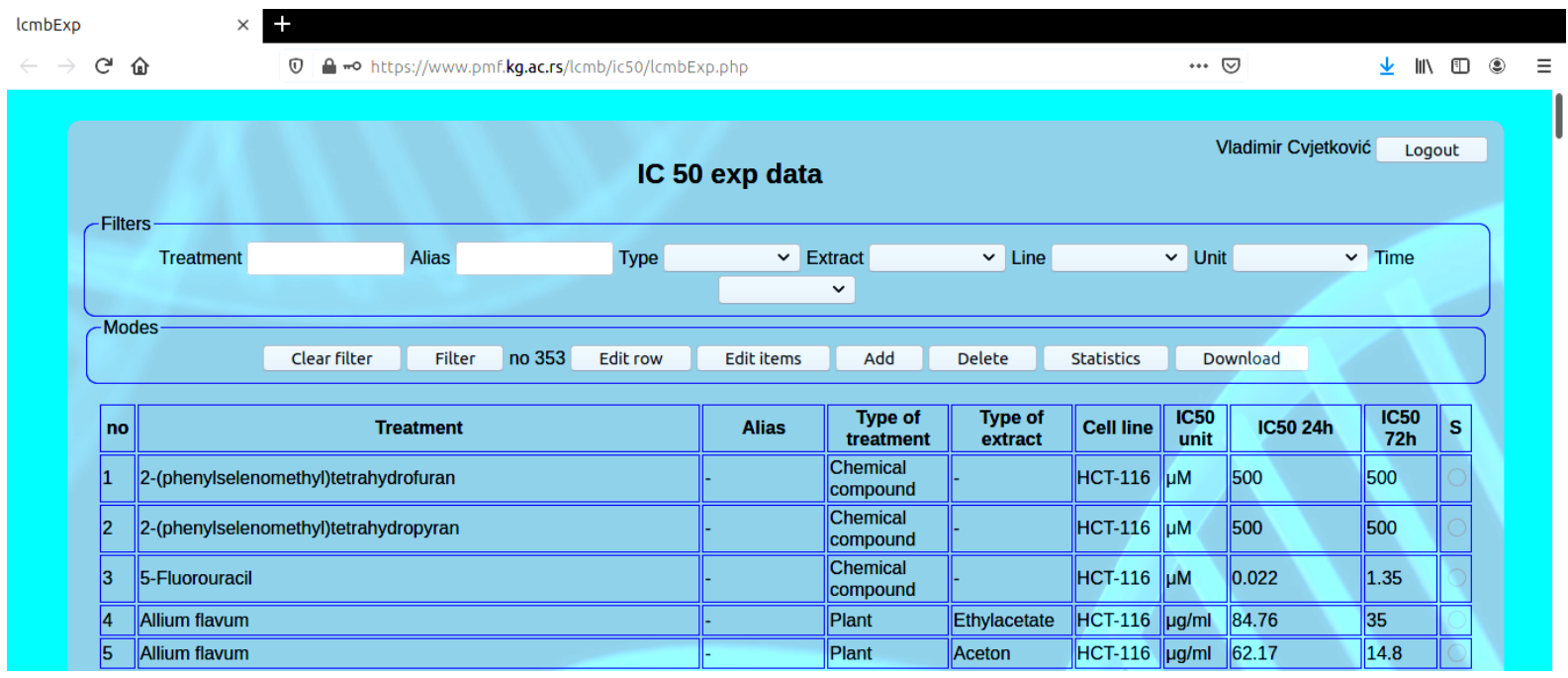

Figure 3. $\mathrm{IC}_{50}$ web application page. 


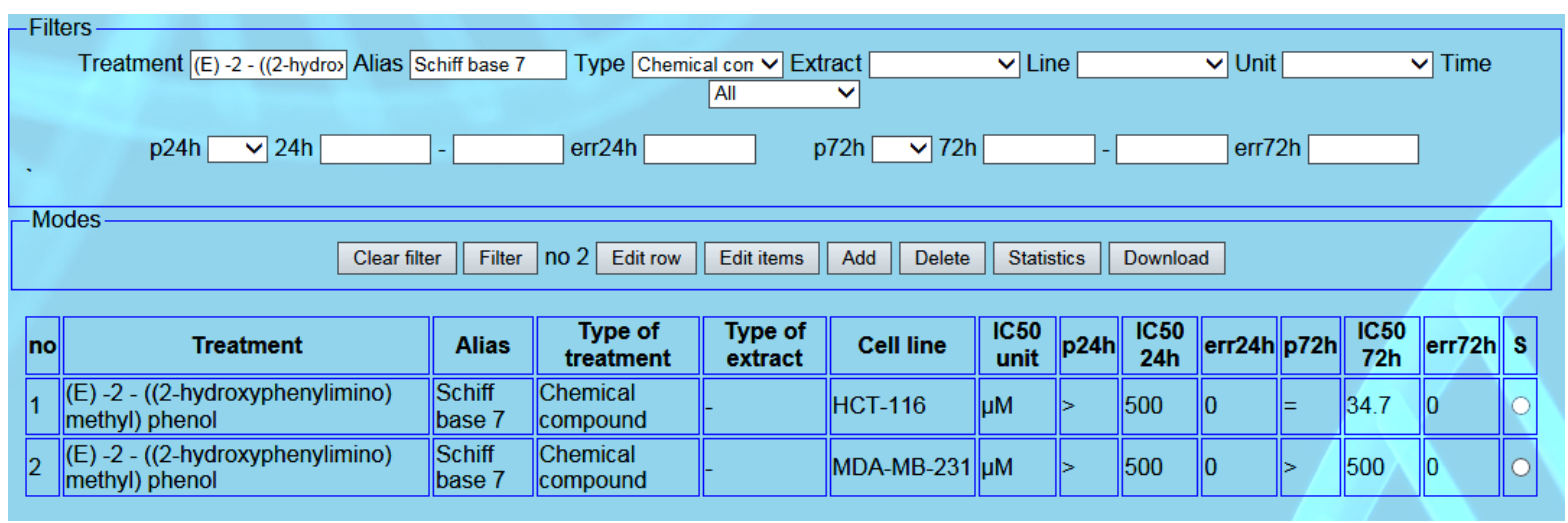

Figure 4. Data filtering.

Error value is estimated as a maximal value for concentration deviation from given nominal $\mathrm{IC}_{50}$ value. Figure 3 shows those additional filtering parameters as text boxes on a web page for entering those values. As for the mentioned filtering parameters, if values are not specified, there is no filtering.

Figure 5 shows web panel for data management CRUD operations. New laboratory experiment data can be added, existing updated, or deleted. Also, new parameter data can be added, updated, or deleted, thus allowing full control of data edit.

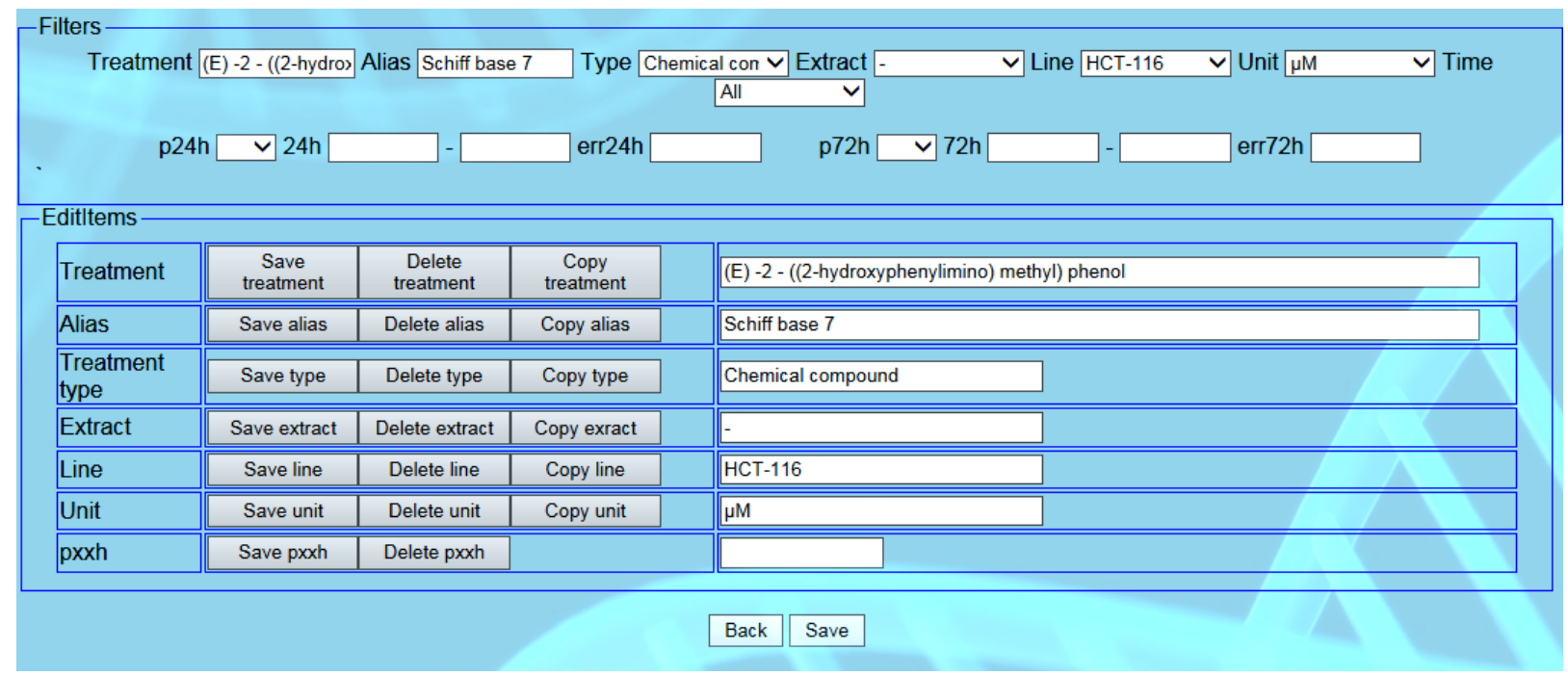

Figure 5. Data management CRUD operations.

Statistical analysis can be performed on any filtered group of $\mathrm{IC}_{50}$ data, according to previously described filtering for data view. Figure 6 shows the statistical panel that consists of 3 main subsections: 1) Single sample, 2) Super or compound sample and 3) ANOVA statistics. Simple sample means that a sample for ANOVA test can be defined according to any possible combination of filtering parameters. Sample name is automatically generated from selected filter parameters, with optional sample name prefix and stored in a sample table with selected values of parameters. Two or more simple samples can be compared by ANOVA sample test. 


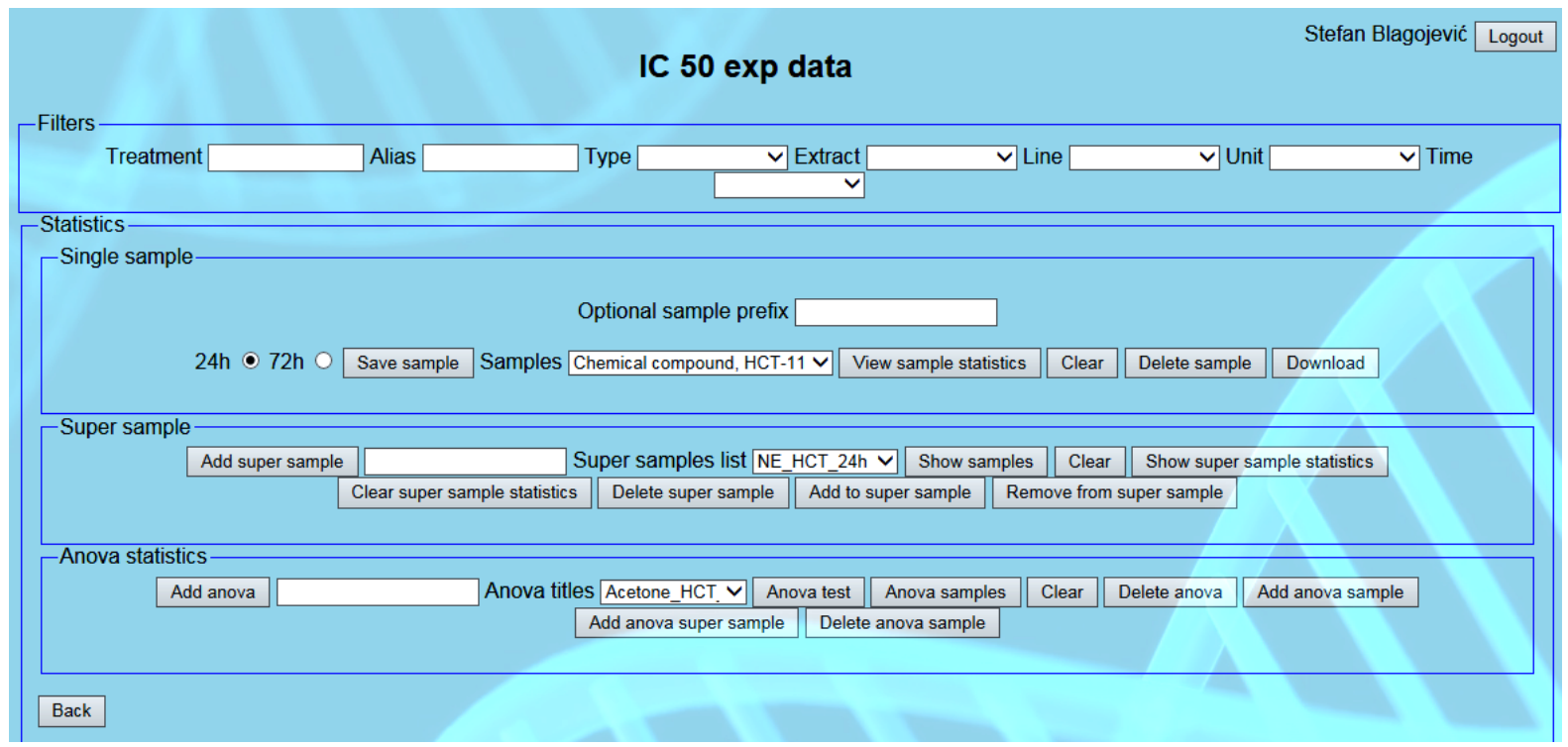

Figure 6. Statistical web application $\mathrm{IC}_{50}$ panel.

Figure 7 shows descriptional statistics for selected single sample, sample size 46 which is number of sample data items, and all sample items.

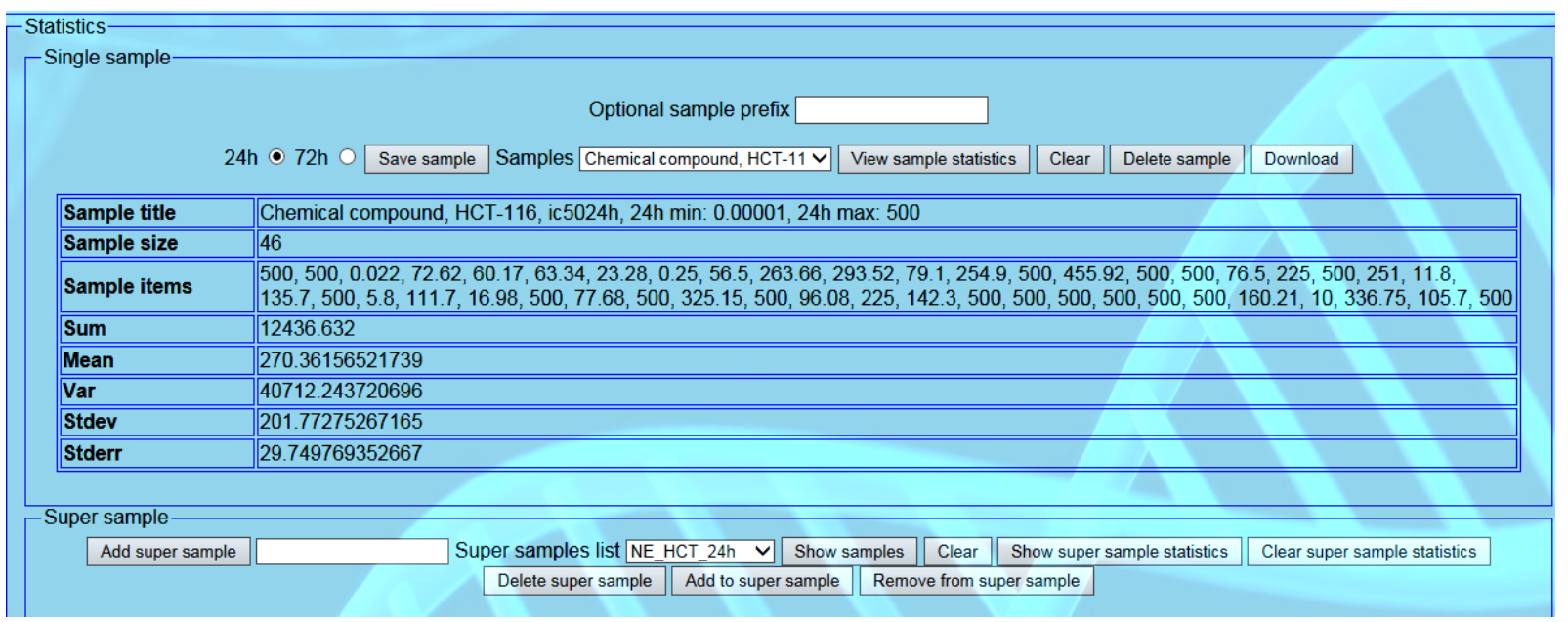

Figure 7. Single sample descriptional statistics.

Figure 8 shows super or compound sample panel. Super sample may consist of one or more previously defined single samples. Super sample consisting of single samples act as one big or compound sample for the ANOVA test. Any combination of two or more single or super samples can be compared with ANOVA test which includes single/single, super/single, or super/super where the number of single/super samples can be one or more. Such samples arrangements offer the flexibility of web application for statistical testing of arbitrary samples. Sample title column in Figure 8 contains titles of all single samples that constitute super sample with title NE_HCT_24h. Each of single samples can be deleted or new single sample added. Similar to the single sample, descriptional statistics for super sample is presented, with a number of super sample data items (No. 69), and all super sample data items listed. Super sample including each single sample is dynamically defined and created from the LCMB IC 50 database for analysis when needed. 


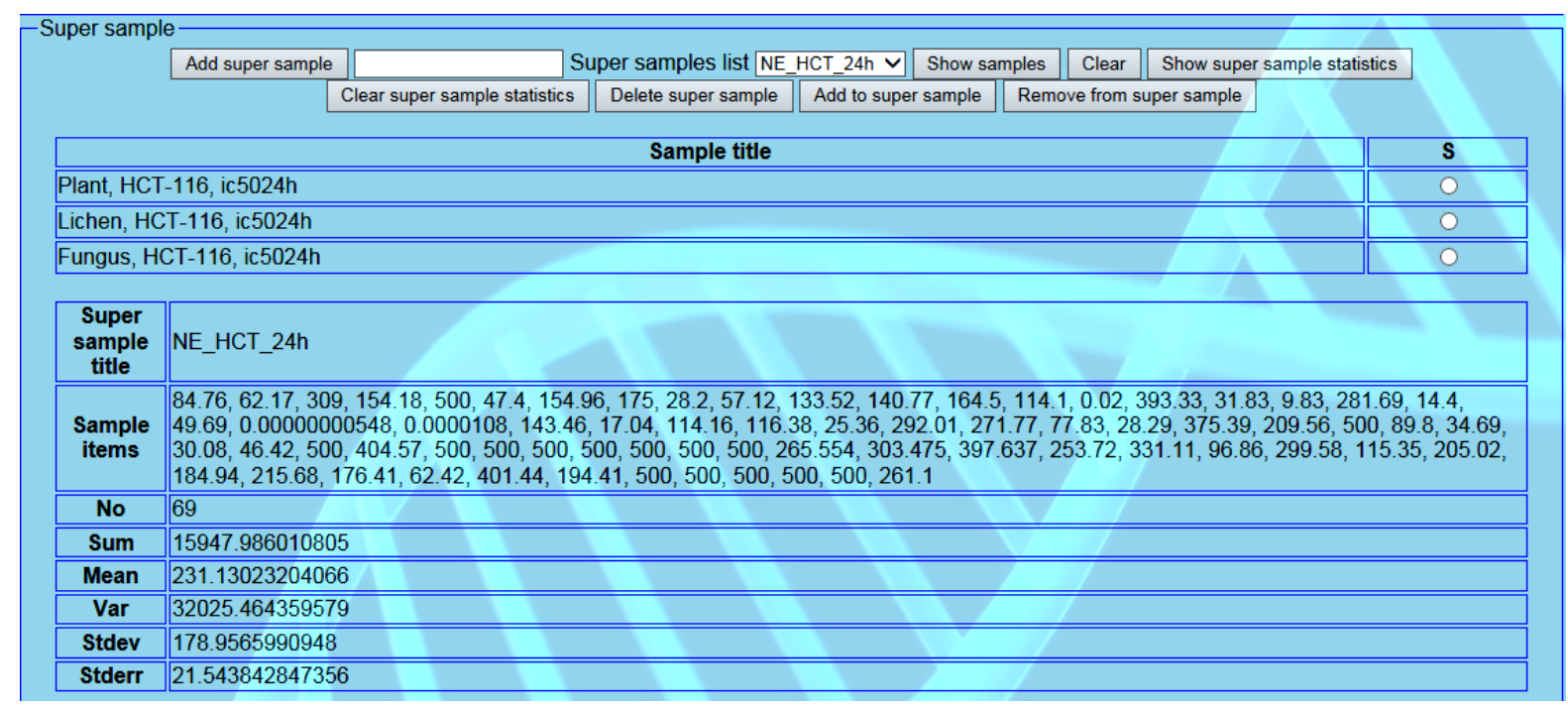

Figure 8. Super sample descriptional statistics.

Figure 9 shows Anova statistics panel. Column Sample title contains single/super sample names for statistical test, 4 samples in this case. In the table below are ANOVA statistical test results. Each of the current samples can be deleted or new samples added to the test.

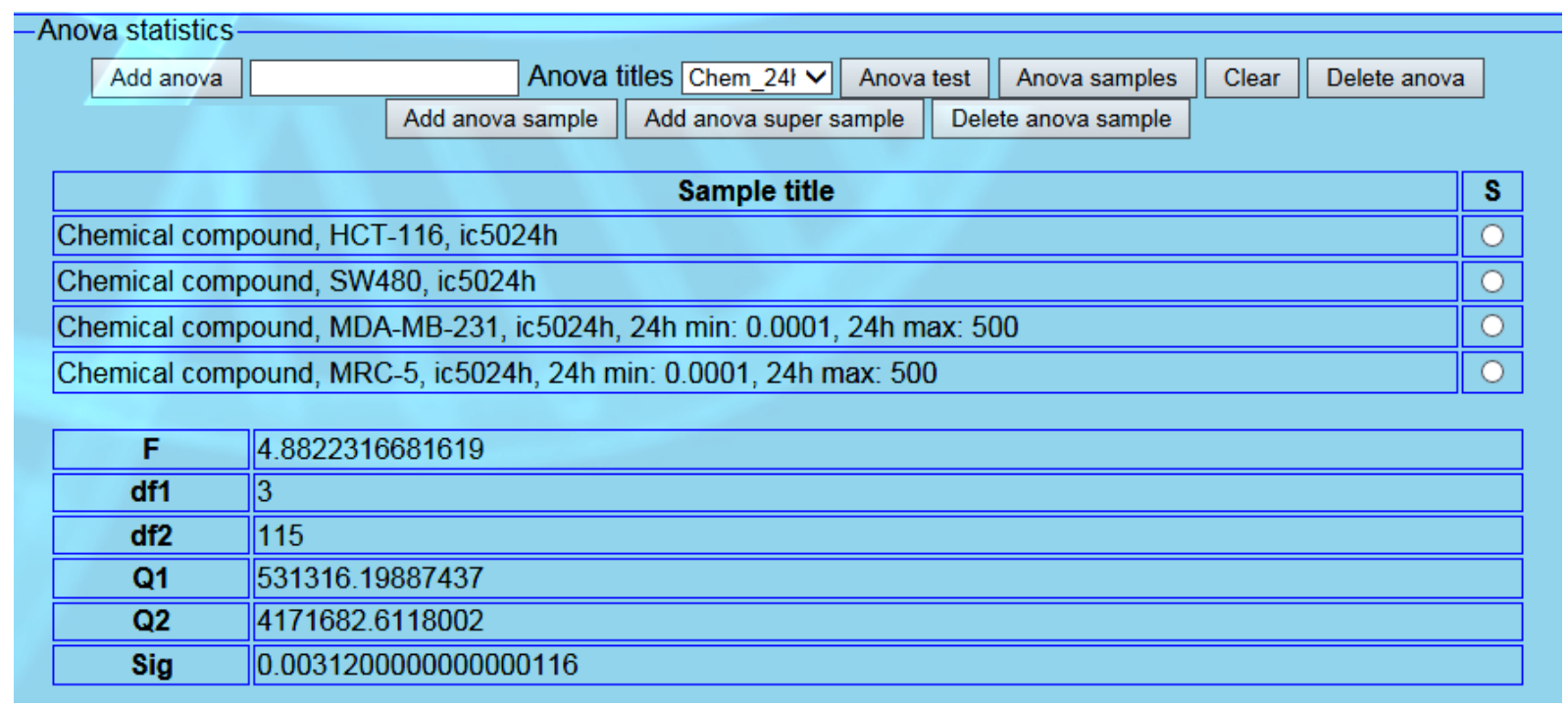

Figure 9. ANOVA statistical test.

\section{RESULTS}

All data for mean, standard error and significance on investigated samples were obtained on the same principle as described in the following example. $\mathrm{IC}_{50}$ values for CHS treatments on HCT-116 cell line after $24 \mathrm{~h}$ which mean value is presented in Table 1 are obtained from descriptive statistics in web application from LCMB $\mathrm{IC}_{50}$ database (Fig. 10). Selected sample with name in Sample title "Chemical compound, HCT-116, ic5024h, 24h min: 0.00001, 24h max: 500" has descriptive statistics with 46 values in Sample size (N). All sample values are listed in Sample items, followed by values for Sum, Mean, Var, Stdev and Stderr. Values for Mean (270.36) and Stderr (29.75) are presented in Table 1 for CHS on HCT-116 cell line after $24 \mathrm{~h}$. 


\begin{tabular}{|c|c|c|c|c|c|}
\hline \multirow{2}{*}{$24 \mathrm{~h} \odot 72 \mathrm{~h} \bigcirc$} & \multirow[t]{2}{*}{ Save sample } & Samples Chemical compound, HCT-11 V & View sample statistics & Clear & Delete sample \\
\hline & & & \multicolumn{3}{|c|}{ Download } \\
\hline Sample title & \multicolumn{5}{|c|}{ Chemical compound, HCT-116, ic5024h, 24h min: $0.00001,24 \mathrm{~h}$ max: 500} \\
\hline Sample size & \multicolumn{5}{|l|}{46} \\
\hline Sample items & \multicolumn{5}{|c|}{$\begin{array}{l}500,500,0.022,72.62,60.17,63.34,23.28,0.25,56.5,263.66,293.52,79.1,254.9,500, \\
455.92,500,500,76.5,225,500,251,11.8,135.7,500,5.8,111.7,16.98,500,77.68,500 \\
325.15,500,96.08,225,142.3,500,500,500,500,500,500,160.21,10,336.75,105.7,500\end{array}$} \\
\hline Sum & \multicolumn{5}{|c|}{12436.632} \\
\hline Mean & \multicolumn{5}{|c|}{270.36156521739} \\
\hline Var & \multicolumn{5}{|c|}{40712.243720696} \\
\hline Stdev & \multicolumn{5}{|c|}{201.77275267165} \\
\hline Stderr & \multicolumn{5}{|c|}{$\mid 29.749769352667$} \\
\hline
\end{tabular}

Figure 10. Descriptive statistics for CHS on HCT-116 cell line after $24 \mathrm{~h}$.

Values for CHS on HCT-116 cell line after $72 \mathrm{~h}$, are obtained from descriptive statistics for sample with Sample title "Chemical compound, HCT-116, ic5072h, 72h min: 0.00001, 72h max: 500" in Figure 11. Sample size of 46, mean value of 231.07 and standard error of 29.61 are presented in Table 1.

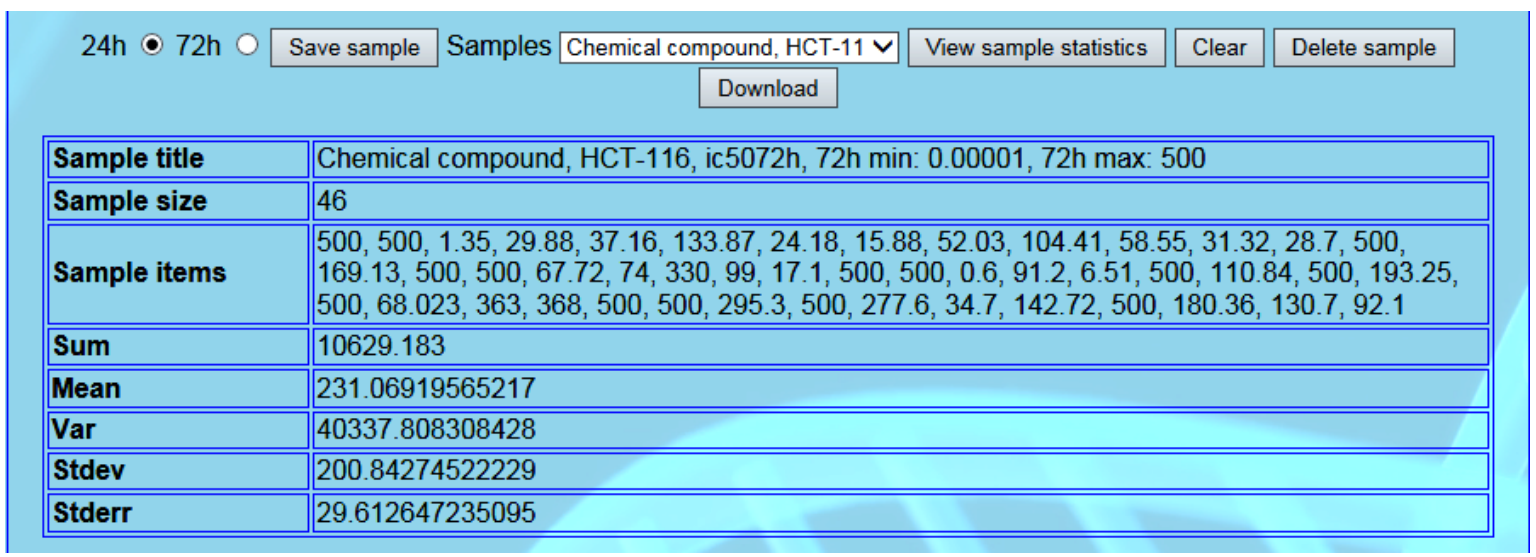

Figure 11. Descriptive statistics for CHS on HCT-116 after 72h.

The $\mathrm{p}$ value of 0.3517 is obtained from ANOVA test named hct116_24_72 which compares previous two samples for CHS on HCT-116 after 24 and 72 h (Fig. 12). Column Sample title contains names of all tested samples (previously mentioned and discussed), with obtained Sig (significance) value of 0.3517 , which is $\mathrm{p}$ value in Table 1.

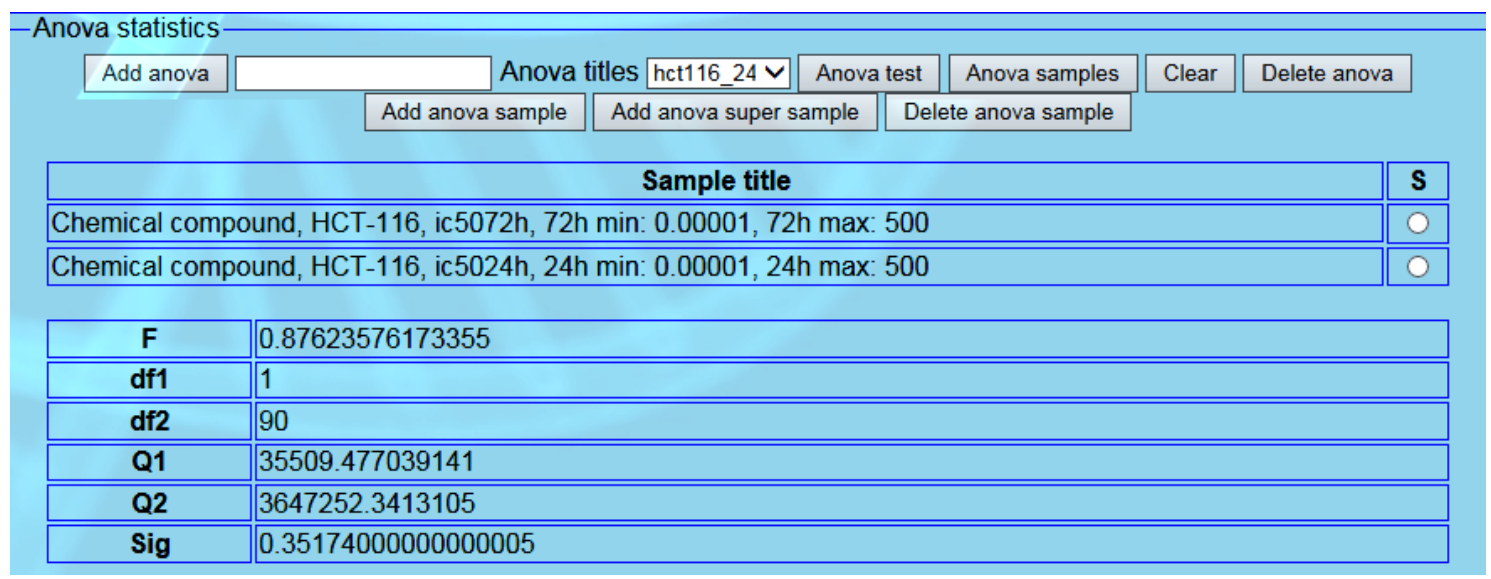

Figure 12. ANOVA test for selected samples. 
ANOVA test between cell lines for $24 \mathrm{~h}$, is presented in Figure 13. It can be seen that four samples are compared, for each cell line. Obtained Sig is 0.0031 which is $\mathrm{p}$ value for CHS between cell lines after $24 \mathrm{~h}$ (Tab. 1).

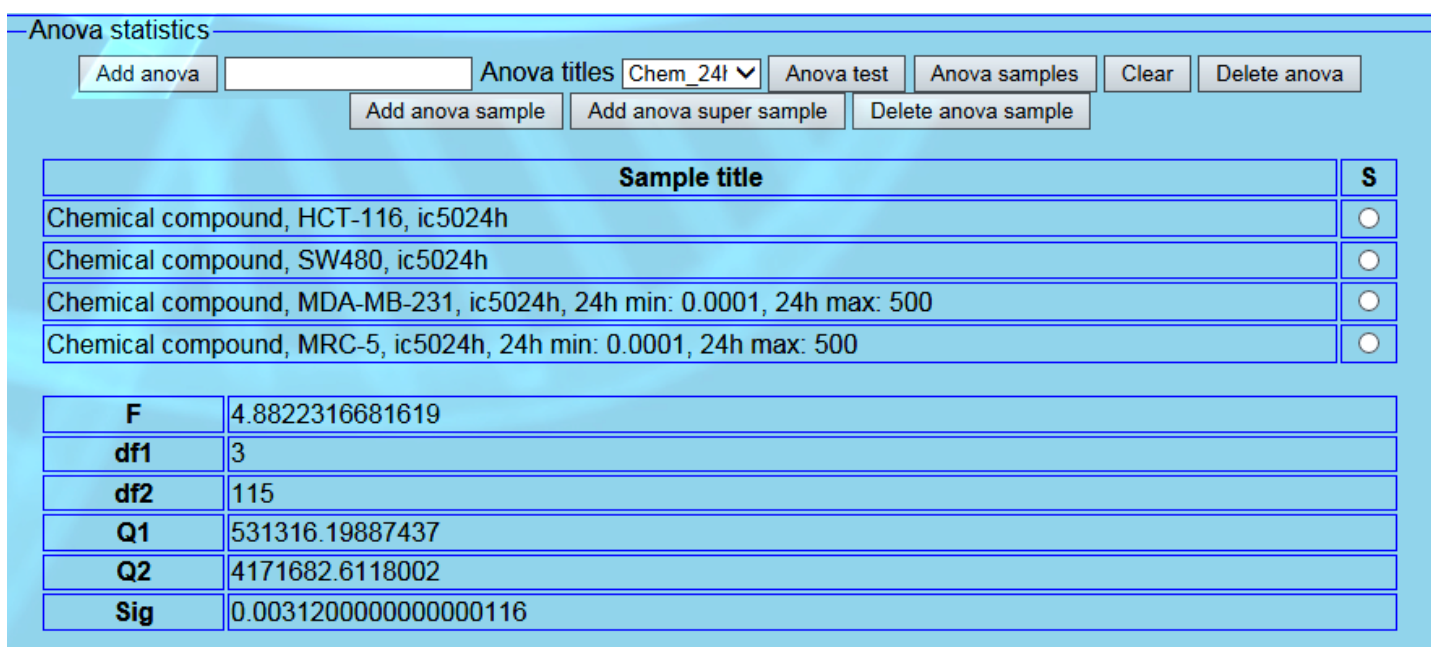

Figure 13. ANOVA test for CHS treatments between cell lines after $24 \mathrm{~h}$.

Analysis of variance for cytotoxicity of BAS was performed depending on the unit in which $\mathrm{IC}_{50}$ values are expressed. The $\mathrm{IC}_{50}$ values differ to their origin: isolated from natural sources (plants, lichen and fungi) expressed in $\mu \mathrm{g} / \mathrm{ml}$ and chemically synthesized expressed in $\mu \mathrm{M}$, which is why the statistical significance was not examined between this two samples. Basic descriptive statistics and values for significance (p) obtained by the ANOVA test from previously presented database, are shown in Table 1. Analysis of variance shows that there is a statistically significant difference in the cytotoxicity of CHS $(\mathrm{p}=0.0031)$ treatments after $24 \mathrm{~h}$ between different cell lines. MRC-5 cell line is the most sensitive in response to CHS treatments and the most resistant to NE treatments. MDA-MB-231 is more resistant to CHS treatments compare to the other cell lines. Analysis of variance for cytotoxicity data of CHS and NE treatments after $72 \mathrm{~h}$ compared to cell lines shows that there is no significant difference. These results indicate a similar sensitivity of the cell lines within the selected treatment conditions after longer incubation time. Table 1 shows that there is no significant difference within cell lines compared to the incubation time of 24 and $72 \mathrm{~h}$, indicating that the treatment acts cytotoxic, constantly during the selected treatment periods. The exception is MDA-MB-231 cells, where CHS treatments show stronger cytotoxic activity over time.

Table 1. Basic descriptive statistics and variance analysis values for $\mathrm{IC}_{50}$ values of CHS $(\mu \mathrm{M})$ and NE $(\mu \mathrm{g} / \mathrm{ml})$ in relation to cancer cell type after 24 and $72 \mathrm{~h}$.

\begin{tabular}{lcccccc}
\hline \multirow{2}{*}{ CHS } & \multicolumn{7}{c}{ Cell line } & \multirow{2}{*}{$\mathbf{p}^{\mathbf{a}}$} & N \\
\cline { 2 - 5 } & $\mathbf{H C T - 1 1 6}$ & $\mathbf{S W - 4 8 0}$ & MDA-MB-231 & MRC-5 & & \\
\hline $\mathbf{2 4} \mathbf{h}$ & $270.36 \pm 29.75$ & $307.34 \pm 48.80$ & $354.12 \pm 27.92$ & $137.73 \pm 44.13$ & $0.0031^{*}$ & $46 / 16 / 42 / 14$ \\
$\mathbf{7 2} \mathbf{~ h}$ & $231.07 \pm 29.61$ & $248.20 \pm 54.68$ & $262.11 \pm 30.74$ & $119.42 \pm 40.53$ & 0.1244 & $46 / 16 / 44 / 15$ \\
$\mathbf{p}^{\mathbf{b}}$ & 0.3517 & 0.4260 & $0.0299^{*}$ & 0.7619 & - & - \\
\hline $\mathbf{N E}$ & \multicolumn{7}{c}{} & & & \\
\hline $\mathbf{2 4} \mathbf{~ h}$ & $231.13 \pm 21.54$ & $231.42 \pm 32.69$ & $309.33 \pm 43.50$ & $356.19 \pm 35.58$ & 0.0598 & $69 / 40 / 18 / 14$ \\
$\mathbf{7 2} \mathbf{~ h}$ & $179.25 \pm 21.32$ & $191.28 \pm 30.46$ & $246.42 \pm 51.87$ & $311.22 \pm 43.45$ & 0.0766 & $69 / 40 / 18 / 14$ \\
$\mathbf{p}^{\mathbf{b}}$ & 0.0892 & 0.3719 & 0.3593 & 0.4251 & - & - \\
\hline
\end{tabular}

The results are present as mean \pm standard error; $\mathrm{p}^{\mathrm{a}}$ - statistical difference between cell lines; $\mathrm{p}^{\mathrm{b}}$ - statistical difference between 24 and $72 \mathrm{~h}$; *statistically significant difference $(\mathrm{p}<0.05)$. 
Analysis of variance shows that there is a statistically significant difference between source of NE (plants, fungi, lichens) on HCT-116 cell line after $24(\mathrm{p}=0.0087)$ and $72 \mathrm{~h}(\mathrm{p}=$ 0.0019) of exposure (Tab. 2). These results indicate that plants show the best cytotoxic effect on HCT-116 cell line after $24 \mathrm{~h}$ and after $72 \mathrm{~h}$ of incubation time. Table 2 shows that there is no significant difference in tested treatment for SW-480 cell line after 24 and $72 \mathrm{~h}$. Mean values show slightly stronger cytotoxic activity of plants after 24 and lichens after $72 \mathrm{~h}$, indicating the different time-dependent effects of these types of treatment on SW-480 cells. There is no statistically significant difference in all tested groups between 24 and $72 \mathrm{~h}$ incubation time.

Table 2. Basic descriptive statistics and analysis of variance for $\mathrm{NE}(\mu \mathrm{g} / \mathrm{ml}) \mathrm{IC}_{50}$ values in treatment of HCT-116, SW-480, MDA-MB-231 and MRC-5 cells after 24 and $72 \mathrm{~h}$ in relation to the source of NE: Plants, Fungi and Lichens.

\begin{tabular}{lcccccc}
\hline \multirow{2}{*}{ Cell line } & \multirow{2}{*}{$\mathbf{h}$} & \multicolumn{2}{c}{ Source of natural extracts } & \multirow{2}{*}{$\mathbf{p}^{\mathbf{a}}$} & \multirow{2}{*}{$\mathbf{N}$} \\
\cline { 3 - 6 } & & $\mathbf{P l a n t s}$ & $\mathbf{F u n g i}$ & $\mathbf{L i c h e n s}$ & & \\
\hline HCT-116 & $\mathbf{2 4}$ & $201.74 \pm 26.87$ & $452.22 \pm 47.78$ & $250.23 \pm 29.73$ & $0.0087^{*}$ & $48 / 5 / 16$ \\
HCT-116 & $\mathbf{7 2}$ & $155.27 \pm 23.95$ & $440.12 \pm 59.88$ & $169.68 \pm 40.67$ & $0.0019^{*}$ & $48 / 5 / 16$ \\
$\mathbf{p}^{\mathbf{b}}$ & & 0.1999 & 0.8784 & 0.1203 & - & - \\
\hline SW-480 & $\mathbf{2 4}$ & $210.45 \pm 38.28$ & $369.10 \pm 80.16$ & $218.04 \pm 89.46$ & 0.2876 & $29 / 5 / 6$ \\
SW-480 & $\mathbf{7 2}$ & $174.01 \pm 37.89$ & $351.20 \pm 74.20$ & $141.50 \pm 26.21$ & 0.1296 & $29 / 5 / 6$ \\
$\mathbf{p}^{\mathbf{b}}$ & & 0.5015 & 0.8739 & 0.4308 & - & - \\
\hline MDA-MB-231 & $\mathbf{2 4}$ & $309.33 \pm 43.50$ & - & - & - & $18 /-/-$ \\
MDA-MB-231 & $\mathbf{7 2}$ & $246.42 \pm 51.87$ & - & - & - & $18 /-/-$ \\
$\mathbf{p}^{\mathbf{b}}$ & & 0.3593 & - & - & - & - \\
\hline MRC-5 & $\mathbf{2 4}$ & $413.22 \pm 46.37$ & - & $280.17 \pm 40.54$ & & $8 /-/ 6$ \\
MRC-5 & $\mathbf{7 2}$ & $317.65 \pm 72.12$ & - & $302.64 \pm 35.69$ & - & $8 /-/ 6$ \\
$\mathbf{p}^{\mathbf{b}}$ & & 0.2838 & - & 0.6862 & - & - \\
\hline
\end{tabular}

The results are present as mean \pm standard error; $\mathrm{p}^{\mathrm{a}}$ - statistical difference between source of natural extracts; $\mathrm{p}^{\mathrm{b}}$ - statistical difference between 24 and $72 \mathrm{~h}$; *statistically significant difference $(\mathrm{p}<0.05)$.

Table 3 presents basic descriptive statistics and analysis of variance for $\mathrm{NE}_{\mathrm{IC}} \mathrm{C}_{50}$ in treatment of HCT-116, SW-480, MDA-MB-231 and MRC-5 cells after 24 and $72 \mathrm{~h}$ in relation to the type of extracts (acetone, methanol and others) used for extraction of BAS. Based on results for significance between investigated type of extracts it can be concluded that all extracts generally adequately isolate the BAS and to exhibit similar activity on HCT-116 cell line, since no significant difference in cytotoxicity was shown depending on the type of extract. Analysis of variance shows that there is a statistically significant difference of NE $\mathrm{IC}_{50}$ values in type of extracts (acetone, methanol and others) on SW-480 cell line after 24 (p $=0.0148$ ) of exposure (Tab. 3). Acetone extracts show stronger cytotoxicity on SW-480 cells than others. There is no statistically significant difference in all tested groups between 24 and $72 \mathrm{~h}$ incubation time. 
Table 3. Values for basic descriptive statistics and analysis of variance for $\mathrm{NE}(\mu \mathrm{g} / \mathrm{ml}) \mathrm{IC}_{50}$ values in treatment of HCT-116, SW-480, MDA-MB-231 and MRC-5 cells after 24 and $72 \mathrm{~h}$ in relation to the type of extracts: Acetone, Methanol and Others.

\begin{tabular}{|c|c|c|c|c|c|c|}
\hline \multirow{2}{*}{ Cell line } & \multirow{2}{*}{$\mathbf{h}$} & \multicolumn{3}{|c|}{ Type of extracts } & \multirow[t]{2}{*}{$\mathbf{p}^{\mathbf{a}}$} & \multirow[t]{2}{*}{$\mathbf{N}$} \\
\hline & & Acetone & Methanol & Others & & \\
\hline HCT-116 & 24 & $228.73 \pm 56.48$ & $236.01 \pm 28.42$ & $223.10 \pm 42.23$ & 0.9652 & $9 / 39 / 21$ \\
\hline HCT-116 & 72 & $108.02 \pm 50.08$ & $194.45 \pm 28.02$ & $181.56 \pm 41.79$ & 0.4235 & $9 / 39 / 21$ \\
\hline $\mathbf{p}^{\mathbf{b}}$ & & 0.1293 & 0.3010 & 0.4885 & - & - \\
\hline SW-480 & 24 & $82.92 \pm 26.43$ & $218.11 \pm 47.11$ & $342.25 \pm 58.25$ & $0.0148 *$ & $8 / 19 / 13$ \\
\hline SW-480 & 72 & $68.48 \pm 32.61$ & $192.69 \pm 42.81$ & $264.81 \pm 60.47$ & 0.0730 & $8 / 19 / 13$ \\
\hline $\mathbf{p}^{\mathbf{b}}$ & & 0.7361 & 0.6920 & 0.3655 & - & - \\
\hline MDA-MB-231 & 24 & 78.49 & $346.26 \pm 44.08$ & $213.96 \pm 144.70$ & - & $1 / 14 / 3$ \\
\hline MDA-MB-231 & 72 & 8.11 & $278.01 \pm 56.63$ & $178.43 \pm 160.81$ & - & $1 / 14 / 3$ \\
\hline $\mathbf{p}^{\mathbf{b}}$ & & - & 0.3504 & - & - & - \\
\hline MRC-5 & 24 & $235.90 \pm 10.02$ & $394.68 \pm 41.06$ & $284.05 \pm 110.25$ & - & $2 / 10 / 2$ \\
\hline MRC-5 & 72 & $291.16 \pm 89.76$ & $330.21 \pm 57.52$ & $236.30 \pm 19.70$ & - & $2 / 10 / 2$ \\
\hline $\mathbf{p}^{\mathbf{b}}$ & & - & 0.3737 & - & - & - \\
\hline
\end{tabular}

The results are present as mean \pm standard error; $\mathrm{p}^{\mathrm{a}}$ - statistical difference between type of extracts; $\mathrm{p}^{\mathrm{b}}$ - statistical difference between 24 and $72 \mathrm{~h}$; *statistically significant difference $(\mathrm{p}<0.05)$.

\section{DISCUSSION}

There is a very limited number of studies that analyze and group the database for the cytotoxic effect of bioactive substances. In the following, in order to examine the different effects of cytotoxicity, we discuss whether and why there are significant differences in the action of BAS of chemically synthesized and natural extracts on HCT-116, SW-480, MDAMB-231 and MRC-5 cell lines, as well as within the treatment incubation period after 24 and $72 \mathrm{~h}$. In addition, results were discussed to investigate the difference in the cytotoxic effect of BAS isolated from plants, fungi or lichens depending on cell lines and incubation period, as well as for the type of extract by which they were isolated.

Based on the results obtained for cytotoxicity of BAS (CHS and NE) to the type of cancer cells treated: HCT-116, SW-480, MDA-MB-231 and MRC-5, it can be concluded that the cell lines are generally stable, because of a large number of data with different values that are included in the assay, as indicated by the standard error. Mean values for $\mathrm{IC}_{50}$ indicate that the MDA-MB-231 cell line is partially more resistant compared to HCT-116, SW-480 and MRC-5, however, this difference is statistically significant only for CHS treatments after 24 $\mathrm{h}$. These cell lines do not originate from the same organ which may lead to different sensitivity to the investigated CHS and NE treatments as a consequence of activation of different signaling pathways and mechanisms of cytotoxicity. Besides, the MDA-MB-231 cell line is metastatic and has highly invasive potential, therefore it can be more resistant to the effects of BAS (AMARO et al., 2016).

Cytotoxic activity of newly synthesized chemical compounds, potential antitumor drugs was investigated based on published results (ŠMIT et al., 2013; JEVTIĆ et al., 2014; KoŠArić et al., 2014; Petrović et al., 2014; Stojković et al. 2014; Petrović et al., 2015; ŽIVANOVIĆ et al., 2017; ŠEKLIĆ, 2018; VUKIĆ et al., 2018b; VuKOVIĆ et al., 2018; RADISAVLJEVIĆ et al., 2019; SOldATOVIĆ et al., 2019; MEDJEDOVIĆ et al., 2020). One of the most commonly used cytostatic in cancer therapy is cisplatin. Cisplatin achieves its antitumor properties by binding to DNA bases of rapidly proliferating cells, but also interacts with 
healthy cells, leading to nephrotoxicity and other adverse effects (STOJKOVIĆ et al. 2014). Due to numerous side effects, there are attempts to synthesize novel chemical agents with easier passage through the cell membrane and the cell itself, as well as easier binding to DNA (FLOREA and BUSSELBERG, 2011). The results of the ANOVA test showed that there was a statistically significant difference between the variable of the tested groups in the effect of treatment with CHS after a $24 \mathrm{~h}$ incubation period between HCT-116, SW-480, MDA-MB231 and MRC-5 cells. Comparing the mean values for $\mathrm{IC}_{50}$ within the tested cell lines higher viability of MDA-MB-231 cells was observed. MDA-MB-231 cell line was proved to be the most resistant on CHS treatment after $24 \mathrm{~h}$, but after longer exposure of $72 \mathrm{~h}$ viability of these cells decreases significantly. Considering the mean values for $\mathrm{IC}_{50}$ in chemical treatments, a stronger cytotoxic effect was observed after $72 \mathrm{~h}$ compared to 24 in all cell lines. This can be explained by the time-dependent effect that chemical treatments have on cancer cells, that is, they also act antiproliferative.

The cytotoxicity results of natural origin (NE) treatments were processed based on published results (Mitrović et al., 2011; STANKOVIĆ et al., 2011; ĆURČIĆ et al., 2012a; ĆURČIĆ et al., 2012b; STANKOVIĆ et al., 2012; GRBOVIĆ et al., 2013; ĆURČIĆ, 2014; KOSANIĆ et al., 2014; AlimpiĆ et al., 2015; MilutinOviĆ et al., 2015a; MilutinOVIĆ et al 2015b; NiKOdiJeviĆ et al., 2016; ŠEKLIĆ et al., 2016; AlimpiĆ et al., 2017a; AlimPiĆ et al., 2017b; DULETIĆ-LAUŠEVIĆ et al., 2018; ŠEKLIĆ et al., 2018; VuKIĆ et al., 2018a; VuKIĆ et al., 2018b; CVetKović et al., 2019; MilutinOviĆ et al., 2019b; MilutinOvić et al., 2019c; GRUJIČIĆ et al., 2020). The results of the ANOVA test showed that there was no statistically significant difference between the mean values of the dependent variable of the test groups in the effect of NE treatment after 24 and $72 \mathrm{~h}$ incubation period between HCT-116, SW-480, MDA-MB-231 and MRC-5 cells. By comparing the cell lines with each other, a slightly higher sensitivity is observed on colon cancer cells HCT-116 and SW-480, while MRC-5 cell line proves to be the most resistant to treatment of natural origin. These results can be linked with the less-toxic effects of natural-source treatments on healthy MRC-5 cells compared to chemicals (GREENWELL and RAHMAN, 2015).

Based on the results obtained for cytotoxicity of BAS of natural origin (NE) in the treatments of SW-480 cells after 24 and $72 \mathrm{~h}$ relative to their source: plants, fungi, lichens, it can be concluded that the cell lines are generally stable and do not differ significantly in sensitivity to treatments. Treatments of natural origin, categorized as plants, fungal and lichen extracts differ in the type of BAS they contain and may, therefore, exhibit similar or different effects of cytotoxicity on different cell lines (MITROviĆ et al, 2011; ĆURČIĆ, 2014; ŠEKLIĆ et $a l ., 2016)$. It was shown that there was a statistically significant difference for cytotoxicity of BAS of natural origin on HCT-116 cells after 24 and $72 \mathrm{~h}$ compared to the source of NE: plants, fungi, lichens. The results of the analysis of variance within these data groups showed that there were no statistically significant differences in the effect of treatment on SW-480 cells for both incubation periods tested. Mushroom-derived treatments were found to be the weakest, while plant and lichen treatments had a slightly stronger and similar cytotoxic effect. The cells of the fruiting bodies of the fungi are rich in sugar components such as glucose, mannose, galactose which can have a beneficial effect on cell proliferation (DOERING et al., 2017). Bioactive substances isolated from different natural sources can activate different signaling pathways and mechanisms of cytotoxicity in cancer cell lines. Given the good cytotoxic effect of lichen, an increasing number of different species have been tested over the past few years (MORIANO, 2016).

Based on the results obtained for cytotoxicity of BAS of NE in treatments on HCT116 cells after $24 \mathrm{~h}$ between the type of extract: methanol, acetone and others, it can be concluded that all the extracts generally adequately isolate the BAS that exhibit similar activity. Comparing the mean values for $\mathrm{IC}_{50}$ on HCT-116 cells over a $72 \mathrm{~h}$ a stronger effect is shown by acetone extract compared to methanolic and others. For SW-480 cells over a 24 
and $72 \mathrm{~h}$ incubation period, a better effect of cytotoxicity was shown by acetone extract compared to methanolic and other extracts. GUPTA et al. (2012) shown that acetone and methanol have been the most effective solvents for the isolation of BAS such as flavonoids and others. Considering the results shown above it can be assumed that acetone extracts additional compounds that can give better effects on SW-480 cells. All types of extracts show time-dependent cytotoxicity on HCT-116, SW-480, MDA-MB-231 and MRC-5 cells.

\section{CONCLUSION}

In this study, newly created LCMB IC $_{50}$ database provides a useful way for storage and comparison of results by different categories: related to the origin of bioactive substances, testing cell line, the origin of cell line, period of incubation, etc. Using the LCMB $\mathrm{IC}_{50}$ database, results were processed and presented in a new way. This kind of data processing has proven to be useful for a further overlook of bases with cytotoxic substances and it can be helpful in the selection and preparation of new BAS, as well as for prediction of their effect in future investigation. Also, database offers the possibility for highlights and selects the BAS with noticeable cytotoxic activity, support for detailed analysis, developing effective anticancer substance and more noticeable selectivity of BAS against one type of cells, for example, cancer vs normal. Statistical data processing of previously observed results can predict the most applicable model system, cell line for chosen treatment, the most applicable cell line for investigation cancer cell resistance to the treatment after a longer time of exposure and response to which type of extract was more effective for natural substances. Using web application for statistical analysis significantly improved not only the speed of analysis but also eliminated potential errors in defining samples and compound samples once they were selected and added to ANOVA statistical test. Simultaneous use of web application by many researchers is possibly contributing to research work efficiency, making it time and place independent for research results analysis. Given that the LCMB IC 50 $_{0}$ database is currently restricted to log-in users only and contains data obtained from the LCMB, this database has the potential to become a global platform for depositing and accessing such results in the future updates, while meeting the requirements for adequate data protection.

\section{Acknowledgments}

This study was financially supported by the Ministry of Education, Science and Technological Development of the Republic of Serbia (Projects no. III41010 until 2020 and Agreement no. 451-03-68/2020-14/200122 in 2020).

\section{References:}

[1] Alimpić, A., Knežević, A., Milutinović, M., Stević, T., Šavikin, K., Stajić, M., Marković, S., Marin, P., Matevski, V., Duletić-LauŠEvić, S. (2017a): Biological activities and chemical composition of Salvia amplexicaulis Lam. extracts. Industrial Crops and Products 105: 1-9. doi: 10.1016/j.indcrop.2017.04.051

[2] Alimpić, A., KnežEvić, A., ŠAvikin, K., ĆurČIĆ, M., VeličKović, D., STević, T., MAtevski, V., Stajić, M., Marković, S., Marin, P.D., Duletić-Laušević, S. (2017b): Composition and biological activities of different extracts of Salvia jurisicii, a rare and endemic Macedonian species. Plant Biosystems 151 (6): 1002-1011. 
doi: 10.1080/11263504.2016.1219414

[3] Alimpić, A., Pljevluakušić, D., Savikin, K., Knezević, A., ĆurČić, M., VeličKović, D., Stević, T., Petrović, G., Matevski, V., Vukojević, J., Marković, S., Marin, P., DulEtiĆ-LauŠEviĆ, S. (2015): Composition and biological effects of Salvia ringens (Lamiaceae) essential oil and extracts. Industrial Crops and Products 76: 702-709. doi: 10.1016/j.indcrop.2015.07.053

[4] Amaro, A., Angelini, G., Mirisola, V., Esposito, A.I., Reverberi, D., Matis, S., Maffei, M., Giaretti, W., Viale, M., Gangemi, R., Emionite, L., Astigiano, S., Cilli, M., Bachmeier, B.E., Killian, P.H., Albini, A., Pfeffer, U. (2016): A highly invasive subpopulation of MDA-MB-231 breast cancer cells shows accelerated growth, differential chemoresistance, features of apocrine tumors and reduced tumorigenicity in vivo. Oncotarget 7 (42): 68803-68820. doi: 10.18632/oncotarget.11931

[5] Caldwell, G.W., Yan, Z., Lang, W., Masucci, J.A. (2012): The IC(50) concept revisited. Current Topics in Medicinal Chemistry 12 (11): 1282-1290. doi: 10.2174/156802612800672844

[6] Chen, H.J., InbaraJ, B.S., Chen, B.H. (2012): Determination of phenolic acids and flavonoids in Taraxacum formosanum kitam by liquid chromatography-tandem mass spectrometry coupled with a post-column derivatization technique. International Journal of Molecular Sciences 13 (1): 260-285. doi: 10.3390/ijms13010260

[7] ĆURČIĆ, M. (2014): Molekularni mehanizmi apoptoze u ćelijama karcinoma kolona nakon in vitro tretmana ekstraktima lekovitih biljaka. PhD thesis, Faculty of Science, University of Kragujevac. [in Serbian]

[8] Ćurčić, M., Stanković, M., Mrkalić, E., Matović, Z., Banković, D., Cvetković, D., ĐAČ́ć, D., MARKOVIĆ, S. (2012a): Antiproliferative and proapoptotic activities of methanolic extracts from Ligustrum vulgare L. as an individual treatment and in combination with palladium complex. International Journal of Molecular Sciences $\mathbf{1 3}$ (2): 2521-2534. doi: 10.3390/ijms13022521

[9] ĆurČić, M., Stanković, M., Radojević, I., Stefanović, O., Čomić, LJ., Topuzović, M., ĐAČIĆ, D., MARKoviĆ, S. (2012b): Biological effects, total phenolic content and flavonoid concentrations of fragrant yellow onion (Allium flavum L.). Medicinal Chemistry 8 (1): 46-51. doi: 10.2174/157340612799278441

[10] Cvetković, D.M., Jovankić, J.V., Milutinović, M.G., Nikodijević, D.D., Grbović, F.J., ĆIRIĆ, A.R., Topuzović, M.D., MARKović, S.D. (2019): The anti-invasive activity of Robinia pseudoacacia L. and Amorpha fruticosa L. on breast cancer MDA-MB-231 cell line. Biologia 74: 915-928. doi: 10.2478/s11756-019-00257-4

[11] Doering, T.L., Cummings, R.D., Aebi, M. (2017): Fungi. Chapter 23 In: Varki, A., Cummings, R.D., Esko, J.D., Stanley, P., Hart, G.W., Aebi, M., Darvill, A.G., Kinoshita, T., Packer, N.H., Prestegard, J.H., Schnaar, R.L., Seeberger, P.H. (eds). Essentials of Glycobiology, 3rd edition. Cold Spring Harbor (NY): Cold Spring Harbor Laboratory Press.

[12] Duletić-Laušević, S., Alimpi, A., Šavkin, K., KneŽević, A., Milutinović, M., SteVić, T., Vukojević, J., Marković, S., Marin, P. (2018): Composition and biological activities of Lybian Salvia fruticosa Mill. and S. lanigera Poir. extracts. South African Journal of Botany 117: 101-109. doi: 10.1016/j.sajb.2018.05.013

[13] Emelyanov P. (2018): On Two Kinds of Dataset Decomposition. In: Shi, Y., Fu, H., Tian, Y., Krzhizhanovskaya, V., Lees, H.M., Dongarra J., Sloot, M.P. (eds). Computational Science - ICCS 2018. Lecture Notes in Computer Science. Springer, Cham 1086: 171-183 pp. doi: 10.1007/978-3-319-93701-4_13

[14] FloreA, A.M., BÜSSElberG, D. (2011): Cisplatin as an anti-tumor drug: cellular mechanisms of activity, drug resistance and induced side effects. Cancers 3 (1): 1351-1371. doi: 10.3390/cancers3011351 
[15] Florento, L., Matias, R., Tuano, E., Santhiage, K., Dela Kruz, F., Tuazon, A. (2012): Comparison of cytotoxic activity of anticancer drugs against various human tumor cell lines using in vitro cell-based approach. International Journal of Biomedical Science 8 (1): 76-80.

[16] Grbović, F., Stanković, M., Ćurčić, M., ĐorĐević, N., ŠEklić, D., Topuzović, M., MARKOVIĆ, S. (2013): In vitro cytotoxic activity of Origanum vulgare L. on HCT-116 and MDA-MB-231 cell lines. Plants 2 (3): 371-378. doi: 10.3390/plants2030371

[17] GReEnwell, M., RahMAN, P.K.S.M. (2015): Medicinal plants: Their use in anticancer treatment. International Journal of Pharmaceutical Sciences and Research 6 (10): 4103-4112. doi: 10.13040/IJPSR.0975-8232.6(10).4103-12

[18] Grujičić, D., Marković, A., Tubić Vukajlović, J., Stanković, M., Radović Jakovljević, M., ĆIrić, A., ĐorĐević, K., Planojević, N., Milutinović, M., Milošević ĐorĐEVIĆ, O. (2020): Genotoxic and cytotoxic properties of two medical plants (Teucrium arduini L. and Teucrium flavum L.) in relation to their polyphenolic contents. Mutation Research/Genetic Toxicology and Environmental Mutagenesis 852: 503168. doi: 10.1016/j.mrgentox.2020.503168

[19] Gupta, A., Naraniwal, M., Kothari, V. (2012): Modern extraction methods for preparation of bioactive plant extracts. International Journal of Agricultural and Natural Sciences 1 (1): 8-26.

[20] Jevtić, V., Radić, G., Šeklić, D., Živanović, M., Marković, S., Trifunović S. (2014): Part XVI - Stereospecific ligands and their complexes: Synthesis, characterization and in vitro antiproliferative activity of new platinum(IV) complexes with some $\mathrm{O}, \mathrm{O}$ '-dialkyl esters of (S,S)-ethylenediamine-N,N'-di-2-propanoic acid against breast cancer (MDA-MB-231) and colon cancer (HCT-116 and SW-480) cell lines. Macedonian Journal of Chemistry and Chemical Engineering 33 (1): 53-58.

[21] Kosanić, M., Šeklić, D., Marković, S., Ranković, B. (2014): Evaluation of antioxidant, antimicrobial and anticancer activity of selected lichens from Serbia. Digest Journal of Nanomaterials and Biostructures 9 (1): 273-287.

[22] Košarić, J., Cvetković, D., Živanović, M., ĆurČić, M., Šeklić, D., Bugarčić, Z., MARKOVIĆ, S. (2014): Antioxidant and antiproliferative evaluation of 2 (phenylselenomethyl) tetrahydrofuran and 2-(phenylselenomethyl) tetrahydropyran. Journal of BUON / Journal of the Balkan Oncology 19 (1): 283-290.

[23] LOPEZ-LAZARO, M. (2015): Two preclinical tests to evaluate anticancer activity and to help validate drug candidates for clinical trials. Oncoscience 2 (2): 91-98. doi: 10.18632/oncoscience.132

[24] Medjedović, M., Simović, A.R., Ćoćić, D., Milutinović, M., Senft, L., Blagojević, S., Milivojević N., Petrović, B. (2020): Dinuclear ruthenium(II) polypyridyl complexes: mechanistic study with biomolecules, DNA/BSA interactions and cytotoxic activity. Polyhedron 178: 114334. doi: 10.1016/j.poly.2019. 114334

[25] Milutinović, M., Čurović, D., Nikodijević, D., Vukajlović, F., Predojević, D., MARKović, S., PeŠIĆ, S. (2019a): The silk of Plodia interpunctella as a potential biomaterial and its cytotoxic effect on cancer cells. Animal biotechnology 29 (4): 1-9. doi: 10.1080/10495398.2019.1575848

[26] Milutinović, M.G., Maksimović, V.M., Cvetković, D.C., Nikodijević, D.D., StanKOVIĆ, M.S., PeŠIć, M.S., MARKOVIĆ, S.D. (2019b) Potential of Teucrium chamaedrys L. to modulate apoptosis and biotransformation in colorectal carcinoma cells. Journal of Ethnopharmacology 240: 111951. doi: 10.1016/j.jep.2019.111951

[27] Milutinović, M., Stanković, M., Cvetković, D., Maksimović, V., Šmit, B., PavloVIĆ, R., MARKoviĆ, S. (2015a): The molecular mechanisms of apoptosis induced by Allium flavum L. and synergistic effects with new-synthesized Pd(II) complex on colon cancer cells. Journal of Food Biochemistry 39 (3): 238-250. doi: 10.1111/jfbc.12123 
[28] Milutinović, M.G., Stanković, M.S., Cvetković, D.M., Šeklić, D.S., Topuzović M.D., Mihailović, V.B., Marković, S.D. (2015b): Antioxidant, antiproliferative and proapoptotic activities of leaves and seed cones from European Yew (Taxus baccata L.). Archives of Biological Sciences 67 (2): 525-534. doi: 10.2298/ABS141006015M

[29] Milutinović, M., Vasić, S., Obradović, A., Zuher, A., Jovanović, M., RadovaNOVIĆ, M., ČOMIĆ, LJ., MARKOVIĆ, S. (2019c): Phytochemical evaluation, antimicrobial and anticancer properties of new "Oligo Grapes" supplement. Natural Product Communications 14 (6): 1-9. doi: 10.1177/1934578X19860371

[30] Mitrović, T., Stamenković, S., Cvetković, V., Tošić, S., Stanković, M., Radojević, I., Stefanović, O., Čomić, LJ, Đačić, D., Ćurčić, M., Marković, S. (2011): Antioxidant, antimicrobial and antiproliferative activities of five lichen species. International Journal of Molecular Sciences 12 (8): 5428-5448. doi: 10.3390/ijms12085428

[31] Moriano, F.C., Burgos, E.G., Divakar, P.K., Crespo, A., Serranillos, M.P.G. (2016): Evaluation of the antioxidant capacities and cytotoxic effects of ten Parmeliaceae Lichen species. Evidence-Based Complementary and Alternative Medicine 2016: 1-11. doi: 10.1155/2016/3169751

[32] Mosmann, T. (1983): Rapid colorimetric assay for cellular growth and survival: application to proliferation and cytotoxicity assays. Journal of Immunology Methods $\mathbf{6 5}$ (12): 55-63.

[33] Ndagi, U., Mhlongo, N., Soliman M.E. (2017): Metal complexes in cancer therapy an update from drug design perspective. Drug Design, Development and Therapy 11: 599-616. doi: 10.2147/DDDT.S119488

[34] Nikodijević, D., Milutinović, M., Cvetković, D., Stanković, M., Živanović, M., MARKOVIĆ, S. (2016): Effects of Teucrium polium L. and Teucrium montanum L. extracts on mechanisms of apoptosis in breast and colon cancer cells. Kragujevac Journal of Science 38: 147-159. doi: 10.5937/KgJSci1638147N

[35] Petrović, V., Simijonović, D., Živanović, M., Košarić, J., Petrović, Z., Marković, S., MARKOvić, S. (2014): Vanillic Mannich bases: Synthesis and screening of biological activity. Mechanistic insight into the reaction with 4-chloroaniline. RSC Advances 4: 24635-24644. doi: 10.1039/C4RA03909B

[36] Petrović, V., Živanović, M., Simijonović, D., Đorović, J., Petrović, Z., Marković, S. (2015): Chelate N,O-palladium(II) complexes: synthesis, characterization and biological activity. RSC Advances 5, 86274-86281. doi: 10.1039/C5RA10204A

[37] Radisavljević, S., Ćoćić, D., Jovanović, S., Šmit, B., PetKović, M., Milivojević, N., Planojević, N., Marković, S., Petrović, B. (2019): Synthesis, characterization, DFT study, DNA/BSA-binding affinity, and cytotoxicity of some dinuclear and trinuclear gold(III) complexes. Journal of Biological Inorganic Chemistry 24: 1057-1076. doi: 10.1007/s00775-019-01716-8

[38] Riss, T.L., MoraveC, R.A., Niles, A.L. (2011): Cytotoxicity testing: measuring viable cells, dead cells, and detecting mechanism of cell death. Methods in Molecular Biology 740: 103-114. doi: 10.1007/978-1-61779-108-6_12

[39] Soldatović, T., Selimović, E., Šmit, B., Ašanin, D., Planojević, N., Marković, S., PuCHTA, R., Alzoubi, M.B. (2019): Interactions of zinc(II) complexes with 5'-GMP and their cytotoxic activity. Journal of Coordination Chemistry 72 (4): 690-706. doi: 10.1080/00958972.2019.1569229

[40] Stanković, M, Ćurčić, M, Žıžić, J, Topuzović, M, Solujić, S, Marković, S. (2011): Teucrium plant species as natural sources of novel anticancer compounds: antiproliferative, proapoptotic and antioxidant properties. International Journal of Molecular Sciences 12 (7): 4190-4205. doi: 10.3390/ijms12074190 
[41] Stanković, M., Radojević, I., Ćurčić, M., Vasić, S., Topuzović, M., Čomić, LJ., MARKOVIĆ, S. (2012): Evaluation of biological activities of goldmoss stonecrop (Sedum acre L.). Turkish Journal of Biology 36: 580-588. doi: 10.3906/biy-1109-9

[42] Stojković, D., Jevtić, V., Radić, G., Đačić, D., Ćurčić, M., Marković, S., Đinović, V., Petrović, V., Trifunović, S. (2014): Stereospecific ligands and their complexes. Part XII. Synthesis, characterization and in vitro antiproliferative activity of platinum(IV) complexes with some O,O'-dialkyl esters of (S,S)-ethylenediamine-N,N'di-2-propanoic acid against colon cancer (HCT-116) and breast cancer (MDA-MB-231) cell lines. Journal of Molecular Structure; 1062: 21-28.

doi: 10.1016/j.molstruc.2014.01.020

[43] ŠEKLIĆ, D. (2018): Molekularni mehanizmi migracije ćelija karcinoma kolona u antitumorskom delovanju novosintetisanih platina (IV) kompleksa i prirodnih bioaktivnih supstanci. PhD thesis, Faculty of Science, University of Kragujevac. [in Serbian]

[44] Šeklić, D., Stanković, M., Milutinović, M., Topuzović, M., ŠTajn, A., Marković, S. (2016): Cytotoxic, antimigratory, pro-and antioxidative activities of extracts from medicinal mushrooms on colon cancer cell lines. Archives of Biological Sciences 68 (1): 93-105. doi: 10.2298/ABS150427131S

[45] Š́eklić, D.S., Obradović, A.D., Stanković, M.S., Živanović, M.N., Mitrović, T.Lu., STAMENKOVIĆ, S.M., MARKOVIĆ, S.D. (2018): Proapoptotic and antimigratory effects of Pseudevernia furfuracea and Platismatia glauca on colon cancer cell lines. Food Technology and Biotechnology 56 (3): 421-430. doi: 10.17113/ftb.56.03.18.5727

[46] ŠMit, B., PAVlović, R., RAdOSAVlJeviĆ-Mihajlović, A., DoŠEn, A., ĆuRČIĆ, M., ŠEKLIĆ, D., ŽIVANOVIĆ, M. (2013): Synthesis, characterization and cytotoxicity of palladium(II) complex of 3-[(2-hydroxy-benzylidene)-amino]-2-thioxo-imidazolidin-4-one. Journal of Serbian Chemical Society 78 (2): 217-227. doi: 10.2298/JSC120725154S

[47] Vukić, M.D., Vuković, N.L., Duelić, G.T., Obradović, A.D., KaCaniova, M.M., MARKović, S.D., Popović, S.LJ., BASKIĆ, D. (2018a): Phytochemical analysis, antioxidant, antibacterial and cytotoxic activity of different plant organs of Eryngium serbicum L. Industrial Crops and Products, 115: 88-97. doi: 10.1016/j.indcrop.2018.02.031

[48] Vukić, M.D., Vuković, N.L., Obradović, A.D., Popović, S.LJ., Zarić, M.M., DJURDJEVIĆ P.M., MARKOVIĆ, S.D., BASKIĆ, D. (2018b): Naphthoquinone rich Onosma visianii Clem (Boraginaceae) root extracts induce apoptosis and cell cycle arrest in HCT-116 and MDA-MB-231 cancer cell lines. Natural Product Research 32 (22): 2712-2716. doi: 10.1080/14786419.2017.1374271

[49] Vuković, N.L., Obradović, A.D., Vukić, M.D., Jovanović, D., Duurdjević, P.M. (2018): Cytotoxic, proapoptotic and antioxidative potential of flavonoids isolated from propolis against colon (HCT-116) and breast (MDA-MB-231) cancer cell lines. Food Research International 106: 71-80. doi: 10.1016/j.foodres.2017.12.056

[50] Wang, H., Khor, T.O., Shu, L., Su, Z., Fuentes, F., Lee, H., Kong, A. (2012): Plants against cancer: A review on natural phytochemicals in preventing and treating cancers and their druggability. Anti-Cancer Agents in Medicinal Chemistry 12 (10): 1281-1305.

[51] Živanović, M.N., KoŠarić, J.V., ŠMit, B., ŠEklić, D.S., PAVlović, R.Z., Marković, S.D. (2017): Novel seleno-hydantoin palladium(II) complex - antimigratory, cytotoxic and prooxidative potential on human colon HCT-116 and breast MDA-MB-231 cancer cells. General Physiology and Biophysics 36: 187-196. doi: 10.4149/gpb_2016036

[52] https://www.php.net/ Accessed 22 April 2020.

[53] https://www.phpmyadmin.net/ Accessed 22 April 2020. 